J. Dairy Sci. 92:286-295

doi:10.3168/jds.2008-1433

(c) American Dairy Science Association, 2009.

\title{
Evaluation of the effects of oral colostrum supplementation during the first fourteen days on the health and performance of preweaned calves
}

\author{
A. C. B. Berge, T. E. Besser, D. A. Moore, and W. M. Sischo ${ }^{1}$ \\ College of Veterinary Medicine, Washington State University, Pullman 99164
}

\begin{abstract}
Increasing concerns about antimicrobial resistance have led to the development and implementation of alternatives to antimicrobial use in animal production. The objective of this clinical trial was to determine the effect of colostrum supplementation of the milk replacer ration on morbidity, mortality, feed intake, and weight gain of preweaned calves. Ninety 1-d-old calves on each of 3 commercial calf ranches were randomly allocated to 1 of 3 groups. Treatment-group calves received 10 $\mathrm{g}$ of supplemental immunoglobulin $\mathrm{G}$ ( $\mathrm{IgG}$ ) in the form of $70 \mathrm{~g}$ of colostrum powder in the milk replacer twice daily for $14 \mathrm{~d}$. The placebo-group calves received a nutritionally equivalent supplement lacking $\operatorname{IgG}$ in the milk replacer twice daily for $14 \mathrm{~d}$. Control calves received milk replacer without supplements twice daily. Calves were housed in individual hutches and were weighed on d 1, 28, and 60. Serum was collected on d 2 for serum IgG determination. Daily health evaluations for the first $28 \mathrm{~d}$ of life were performed by study personnel blinded to treatment group assignment. Observed illness was treated based on health assessment, rectal temperature, and specific calf ranch protocols. Feed consumption (milk and grain) was recorded. Calves receiving supplemental colostrum had less diarrhea and received fewer antimicrobial treatments than control and placebo calves. The results indicated that calf diarrhea was associated with low serum IgG levels and low-weight calves. Grain consumption and weight gain over the first $28 \mathrm{~d}$ of life were significantly greater in colostrum-supplemented calves compared with control calves. No differences in mortality or respiratory disease incidence among groups were detected. Supplemental colostrum during the first 2 wk of life can reduce diarrheal disease in preweaned calves on calf ranches and thereby reduce the amount of antimicrobial treatments needed.
\end{abstract}

Key words: colostrum, dairy calf, antimicrobial resistance, diarrhea

Received June 6, 2008.

Accepted September 1, 2008.

${ }^{1}$ Corresponding author: wmsischo@vetmed.wsu.edu

\section{INTRODUCTION}

There are concerns that prophylactic and metaphylactic uses of antimicrobial drugs in food animal production increase antimicrobial resistance with potential adverse effects on human health (FAO/WHO/ OIE, 2008; Silbergeld et al., 2008). Animal agriculture industries are being encouraged to reduce the use of all types of antimicrobial drugs, to find nonantimicrobial alternatives for nontherapeutic needs, and to optimize animal health through management approaches.

One area of focus in the dairy and beef industry is calves on calf ranches being reared as dairy heifer replacements or bull calves for beef. A key aspect to successfully rearing these animals is to ensure adequate intake of colostrum to support the animal's passive immunity. Calves with adequate passive transfer of immunity have lower mortality and morbidity and fewer antibiotic treatments compared with animals with failure of passive transfer (Berge et al., 2005). Despite the general knowledge of the importance of feeding colostrum to the neonatal calf, calves arrive at calf ranches with suboptimal serum immunoglobulin levels (Besser et al., 1991; Besser and Gay, 1994; Hopkins and Quigley, 1997). To address this problem, it is a widely accepted practice to feed antimicrobials to preweaned calves (Braidwood and Henry, 1990; Constable, 2003; Glantz et al., 1974; Quigley et al., 1997).

To properly provide support to systemic immunity, good quality colostrum needs to be administered in appropriate volumes as early as possible within the first $24 \mathrm{~h}$ after birth (Weaver et al., 2000). However, there is evidence that antibodies remaining in the gut lumen after colostrum feeding also provide local immunity against enteric viral infections and diarrhea caused by bacterial enterotoxins and may enhance intestinal villus development (Snodgrass et al., 1980, 1982; Saif and Bohl, 1983; Buhler et al., 1998). Given this observation, in the absence of properly administered colostrum, it is possible that a colostrum supplement could provide local gut immunity and decrease the need for supplemental antimicrobials in colostrum-deprived calves. The objective of this study (a multisite clinical trial) was to determine the effect of oral IgG supplementa- 
tion on preweaned calf mortality, morbidity, weight gain, and feed intake. The hypothesis was that oral IgG supplementation during the early preweaning period decreases calf mortality and morbidity.

\section{MATERIALS AND METHODS}

\section{Study Sites}

Colostrum supplementation trials were performed at 3 California calf ranches raising dairy-source calves: bull calves reared for beef (ranch A), mixed bull beef and heifer replacements (ranch B), and bull beef (ranch C). The studies were conducted between October 2005 and September 2006. On ranch A, the calves were fed milk replacer $[22 \% \mathrm{CP}$ and $18 \%$ crude fat $(\mathbf{C F})]$ medicated with neomycin and tetracycline. On ranch $\mathrm{B}$, the calves were fed milk replacer $(22 \% \mathrm{CP}$ and $22 \%$ $\mathrm{CF})$ medicated with neomycin and tetracycline for the first $2 \mathrm{wk}$; thereafter, the calves received pasteurized hospital milk medicated with tetracycline. On ranch C, the calves were fed nonmedicated milk replacer $(22 \%$ $\mathrm{CP}$ and $18 \% \mathrm{CF}$ ). On all 3 ranches, it was standard procedure for calves to receive a colostrum supplement at the first feeding (usually the afternoon) following delivery to the ranch. Calves were bottle-fed $1.89 \mathrm{~L}$ of milk replacer or milk twice daily. Fresh water and fresh calf starter grain in buckets were administered daily.

\section{Study Design and On-Farm Procedures}

A minimum of ninety 1- to 3-d-old Holstein calves were enrolled at each calf ranch and randomly allocated to 1 of 3 treatment groups: colostrum supplement (CS), placebo supplement (PS), or unsupplemented control (UC). The assumptions for calculating the sample size were type I error $=0.10$, type II error $=0.10$, detecting a difference of a mean 5 diarrhea days for UC and PC calves compared with $3.5 \mathrm{~d}$ for CS calves, and a sample standard deviation of $2 \mathrm{~d}$. The estimated sample size was inflated to allow for a $15 \%$ loss to follow-up.

The CS group received $70 \mathrm{~g}$ of dried colostrum powder (Calves Choice Total Bronze, Saskatoon Colostrum Co. Ltd., Saskatchewan, Canada), containing $10 \mathrm{~g}$ of IgG in each of 2 daily milk replacer meals for $14 \mathrm{~d}$. The colostrum powder contained $45 \% \mathrm{CP}, 26 \% \mathrm{CF}$, $13 \%$ lactose, $5 \%$ ash, and gross energy of $5.9 \mathrm{Mcal} /$ $\mathrm{kg}$ of DM corresponding to $231 \mathrm{kcal} / 70 \mathrm{~g}$ of powder. The PS group similarly received $70 \mathrm{~g}$ of milk replacer powder, matched to the colostrum supplement, with $45 \% \mathrm{CP}$ and $26 \% \mathrm{CF}$ (Calva Products Inc., Acampo, CA), but did not contain IgG. The UC group received no addition to their milk replacer formula. The supplements were mixed in $2.4 \mathrm{dL}$ of warm water and added to bottles before addition of the milk replacer powder. Study personnel were in charge of all feedings.

Calves were independently evaluated daily by study personnel blinded to calf treatment group. They were evaluated for morbidity, which included fecal consistency, attitude, hydration, and respiratory scores (Berge et al., 2005). If any abnormalities were noted, then a rectal temperature was obtained. All treatments in the first $28 \mathrm{~d}$ were performed and recorded by study personnel based on treatment protocols agreed upon with farm management. Each course of antimicrobial treatment was $3 \mathrm{~d}$ or longer, in accordance with label instructions or the farm-specific treatment protocols. Diarrheal disease was defined as watery and/or bloody feces. Respiratory scores were 1 for nasal discharge, 2 for coughing, 3 for heavy thoracic breathing, and 4 for abdominal breathing. Respiratory disease was defined as a score 3 or 4 . All calves with diarrhea or respiratory disease were treated with antimicrobial drugs as described above. All calves were weighed 3 times during the trial on a mechanical scale (with accuracy to the nearest $1 \mathrm{lb}$.): at entry into the trial, $28 \mathrm{~d}$ on the farm, and at weaning $(60 \mathrm{~d})$. Feed consumption (milk and grain) were recorded for $28 \mathrm{~d}$. After $28 \mathrm{~d}$, management of the calves was taken over by the calf ranch. Study personnel returned to measure weaning weight.

\section{Passive Transfer of Immunity}

Blood samples from all calves were collected on the day after arrival (d 2) at the ranch. On ranch A, blood samples were also collected on $\mathrm{d} 7$ to evaluate if colostrum supplementation modified the serum IgG levels in the calves. Serum IgG levels were determined using a commercial radial immunodiffusion assay (Immunocheck, VMRD, Pullman, WA).

\section{Data Analysis}

Health and treatment data were recorded in a spreadsheet program (Excel, Microsoft Corp., Redmond, WA) and analyzed using a statistical software program (version 9.1, SAS Institute Inc., Cary, NC). Ninety percent confidence intervals were calculated for all main effect estimates. Interactions between all main effects were tested and retained in the models if their $P$-values were $\leq 0.1$.

Passive Transfer of Immunity. Passive transfer of immunity status was classified as failure of passive transfer $(\mathbf{F P T})$ for $\operatorname{IgG} \leq 350 \mathrm{mg} / \mathrm{dL}$, partial failure of passive transfer (PFPT) for values from 351 to 999 $\mathrm{mg} / \mathrm{dL}$, and adequate passive transfer (APT) for IgG $\geq 1,000 \mathrm{mg} / \mathrm{dL}$ (Tyler et al., 1996; Berge et al., 2005). 
Table 1. Descriptive statistics of serum IgG category and arrival weights stratified by treatment group from 3 field trials evaluating the efficacy of feeding a colostrum supplement in milk replacer for $14 \mathrm{~d}$ to preweaned calves

\begin{tabular}{|c|c|c|c|c|c|c|c|c|c|c|c|}
\hline $\begin{array}{l}\text { Treatment } \\
\text { group }^{1}\end{array}$ & \multicolumn{2}{|c|}{ Serum IgG, mg/dL } & \multicolumn{4}{|c|}{ IgG category, ${ }^{2} n\left(n_{\text {dead }}\right)$} & \multicolumn{2}{|c|}{ Arrival weight, $\mathrm{kg}$} & \multicolumn{3}{|c|}{ Weight category, ${ }^{3} \mathrm{n}$} \\
\hline CS & 1,147 & 1,138 & $92(13)$ & $34(1)$ & $44(6)$ & $14(6)$ & 41.3 & 5.7 & 36 & 32 & 24 \\
\hline UC & 1,352 & 1,711 & $90(12)$ & $36(0)$ & $36(5)$ & $18(7)$ & 41.8 & 5.3 & 26 & 36 & 28 \\
\hline Total & 1,236 & 1,372 & $273(38)$ & $104(2)$ & $117(15)$ & $52(21)$ & 41.7 & 5.4 & 84 & 111 & 78 \\
\hline
\end{tabular}

${ }^{1} \mathrm{CS}=$ colostrum supplement (70 g of dried colostrum powder) added to milk replacer; PS = placebo supplement (70 g of nutritionally matched supplement without $\mathrm{IgG}$ ) added to milk replacer; UC = unsupplemented control.

${ }^{2} \mathrm{APT}=$ adequate passive transfer: $\mathrm{IgG} \geq 1,000 \mathrm{mg} / \mathrm{dL} ; \mathrm{PFPT}=$ partial failure of passive transfer: IgG between (and including) 351 and 999 $\mathrm{mg} / \mathrm{dL}$; and $\mathrm{FPT}=$ failure of passive transfer: $\mathrm{IgG} \leq 350 \mathrm{mg} / \mathrm{dL}$.

${ }^{3}$ Low: $\leq 38.5 \mathrm{~kg}$; mid: between 38.6 and $45 \mathrm{~kg}$; high: $\geq 45 \mathrm{~kg}$.

Arrival Weights. Calf weights taken when the calves were initially processed on arrival to the ranch were classified as low for weights $\leq 38.5 \mathrm{~kg}(80 \mathrm{lb}$. $)$, mid for weights between 38.6 and $44.9 \mathrm{~kg}$ (80 to $100 \mathrm{lb}$.), and high for weights $\geq 45 \mathrm{~kg}$ (100 lb.).

Mortality. Mortality in calves during the first $28 \mathrm{~d}$ was evaluated using univariate Kaplan-Meier survival plots. The Cox proportional hazard model was used for multivariate assessment of mortality. Proportionality of hazards was assessed by plotting $\ln [-\ln$ (survival)] against $\ln$ (calf-days), including time-dependent interactions for each of the predictive variables in the proportional hazard model and using a linear proportionality test (Allison, 2007). Hazard rate ratios and 90\% confidence intervals for the main effect (treatment group) and each covariate (calf ranch, arrival weight category, and serum IgG category) were determined (Hosmer and Lemeshow, 1999).

Morbidity. The percentage of days that the calves had diarrhea and were treated for diarrhea was calculated. The number of days a calf was observed with diarrhea during the days at risk conditional on treatment group was assessed using a negative binomial model (Allison, 2005). Treatment group was the main effect evaluated and confounding variables included calf ranch, calf arrival weight category, and calf IgG category. The days to first antimicrobial treatment for diarrhea conditional on treatment group, including the same confounding variables, was evaluated using the survival analysis approach described previously for mortality. Difference in respiratory morbidity (based on an ordinal severity scale) between treatment groups was assessed using the Jonckheere-Terpstra nonparametric test for trend (Hollander and Wolfe, 1999).

$A D G$ and Grain Intake. A general linear model calculating least squares means was used to compare treatment differences in ADG up to $28 \mathrm{~d}$ of age and at weaning $(60 \mathrm{~d})$. Least squares mean estimates and $90 \%$ confidence intervals were calculated for the main effect of treatment group and the covariates of calf ranch, arrival weight category, and serum IgG category. Grain consumption was measured daily for $28 \mathrm{~d}$ and the average daily intake was calculated. The same main effect and covariate set used for ADG were used to evaluate grain intake.

\section{RESULTS}

The 3 clinical trials included 273 calves: 91 at ranch A, 90 at ranch B, and 92 at ranch C. Calves that died before obtaining the blood sample for serum IgG evaluation on the day after arrival (3 calves on ranch $\mathrm{C}$ ) were excluded from the study

\section{Passive Transfer of Immunity and Birth Weights}

Failure of passive transfer was common in the study calves, with 19, 43, and 38\% in IgG categories FPT, PFPT, and APT, respectively (Table 1). On ranch A, the serum IgG of calves was not significantly different at $\mathrm{d} 7$ between calves in the 3 treatment groups (data not shown). The calves were categorized into arrival weight categories; $31 \%$ low, $41 \%$ mid, and $29 \%$ high (Table 1).

\section{Mortality}

Mortality rates over the first $28 \mathrm{~d}$ of the trials were $7.7,7.8$, and $26.1 \%$ on ranches $\mathrm{A}, \mathrm{B}$, and $\mathrm{C}$, respectively. The proportional hazard model indicated that there was no significant influence of colostrum supplement on mortality (Table 2). The hazard of dying in calves with FPT or PFPT was 26 or 6 times greater, respectively, than in calves with APT.

\section{Morbidity}

Over the 28-d trial period, the overall percentage of days that diarrhea was observed was $8.8 \%$, with the colostrum-supplemented group having the lowest percent- 
Table 2. Results from a multivariate proportional hazards model of mortality in calves during the first $28 \mathrm{~d}$ of life from 3 field trials (ranches A, B, and C) evaluating the efficacy of feeding a colostrum supplement in milk replacer for $14 \mathrm{~d}$ to preweaned calves

\begin{tabular}{|c|c|c|c|c|c|}
\hline \multirow[b]{2}{*}{ Variable } & \multirow[b]{2}{*}{ Level } & \multirow[b]{2}{*}{ Hazard ratio } & \multicolumn{2}{|c|}{$90 \% \mathrm{CI}^{1}$} & \multirow[b]{2}{*}{ Wald's $P$-value } \\
\hline & & & Lower & Upper & \\
\hline \multirow[t]{3}{*}{ Treatment group ${ }^{2}$} & $\mathrm{CS}$ & 1.02 & 0.52 & 1.98 & 0.96 \\
\hline & PS & 0.86 & 0.44 & 1.69 & 0.72 \\
\hline & \multicolumn{5}{|c|}{ Weight category ${ }^{3}$} \\
\hline & Low & 0.96 & 0.44 & 2.07 & 0.93 \\
\hline & Mid & 0.71 & 0.33 & 1.52 & 0.46 \\
\hline \multicolumn{6}{|l|}{ Serum IgG status ${ }^{4}$} \\
\hline Seruml IgG stalus & FPT & 26.22 & 7.60 & 90.38 & $<0.01$ \\
\hline & PFPT & 5.88 & 1.68 & 20.52 & 0.02 \\
\hline & $\mathrm{APT}$ & Reference & - & - & - \\
\hline \multirow{3}{*}{ Calf ranch } & $\mathrm{A}$ & 0.29 & 0.14 & 0.60 & $<0.01$ \\
\hline & B & 0.44 & 0.21 & 0.95 & 0.08 \\
\hline & $\mathrm{C}$ & Reference & - & - & - \\
\hline \multicolumn{6}{|c|}{${ }^{1} \mathrm{CI}=$ confidence interval. } \\
\hline \multicolumn{6}{|c|}{$\begin{array}{l}{ }^{2} \mathrm{CS}=\text { colostrum supplement }(70 \mathrm{~g} \text { of dried colostrum powder }) \text { added to milk replacer; } \mathrm{PS}=\text { placebo supple- } \\
\text { ment }(70 \mathrm{~g} \text { of nutritionally matched supplement without } \mathrm{IgG}) \text { added to milk replacer; } \mathrm{UC}=\text { unsupplemented } \\
\text { control. } \\
{ }^{3} \text { Low: }<38.5 \mathrm{~kg} \text {; mid: between } 38.6 \text { and } 45 \mathrm{~kg} \text {; high: }>45 \mathrm{~kg} \text {. }\end{array}$} \\
\hline
\end{tabular}

age of diarrhea days (Table 3). From the multivariate negative binomial model assessing number of diarrhea days, calves receiving the colostrum supplement had fewer diarrheal days compared with unsupplemented controls (relative risk $=0.61 ; 90 \% \mathrm{CI}=0.49-0.78$; Table 4). There was no difference in the risks of diarrhea between placebo supplemented and unsupplemented control calves (relative risk $=1.07 ; 90 \% \mathrm{CI}=$ 0.86-1.32). Calves with FPT and PFPT had increased risk for diarrhea compared with calves with APT. Lowand mid-weight calves also tended to have greater risk for diarrhea than high-arrival-weight calves.
Overall, calves were treated with antimicrobials (primarily for diarrheal disease) for approximately $10 \%$ of the total study calf-days (Table 3). Calves in the colostrum-supplemented group had the lowest percentage of treatment days. The Kaplan-Meier plot indicated significant differences (Wilcoxon test equality of strata: $\left.\chi^{2}=7.53 ; P=0.02\right)$ in days to first treatment of diarrhea between the groups (Figure 1). The multivariate proportional hazard model controlling for other factors similarly showed that calves in the colostrum supplemented group had a significant increase in days to antimicrobial treatment (hazard ratio $=0.57$;

Table 3. Descriptive statistics of ADG, total calf study days (total days), number (\%) of days calves observed with diarrhea and respiratory disease, number (\%) of days calves treated with antimicrobials (treatment days), and average grain and milk intake stratified by treatment group from 3 field trials evaluating the efficacy of feeding a colostrum supplement in milk replacer for $14 \mathrm{~d}$ to preweaned calves

\begin{tabular}{|c|c|c|c|c|c|c|c|c|c|c|c|}
\hline \multirow{2}{*}{$\begin{array}{l}\text { Treatment } \\
\text { group }^{1}\end{array}$} & \multicolumn{4}{|c|}{$\mathrm{ADG}, \mathrm{kg}$} & \multicolumn{3}{|c|}{ Disease days } & \multirow{2}{*}{$\begin{array}{c}\text { Treatment } \\
\text { days }(\%)\end{array}$} & \multicolumn{3}{|c|}{ Feed consumption ${ }^{2}$} \\
\hline & \multicolumn{2}{|c|}{ d 28} & \multicolumn{2}{|c|}{ d 60} & $\begin{array}{l}\text { Total } \\
\text { days }\end{array}$ & $\begin{array}{c}\text { Diarrhea } \\
\text { days, } \\
\text { n }(\%)\end{array}$ & $\begin{array}{c}\text { Resp }^{3} \\
\text { days, n (\%) }\end{array}$ & & $\begin{array}{l}\text { Grain, } \\
\text { kg }\end{array}$ & $\begin{array}{l}\text { a.m. } \\
\text { milk, L }\end{array}$ & $\begin{array}{l}\text { p.m. } \\
\text { milk, L }\end{array}$ \\
\hline$\overline{\mathrm{CS}}$ & 0.28 & 0.17 & 0.55 & 0.2 & 2,210 & $147(6.1)$ & $24(1.0)$ & $196(8.2)$ & 0.23 & 1.87 & 1.85 \\
\hline PS & 0.23 & 0.18 & 0.51 & 0.16 & 2,096 & $255(10.7)$ & $35(1.46)$ & $293(12.3)$ & 0.23 & 1.86 & 1.86 \\
\hline UC & 0.22 & 0.15 & 0.52 & 0.18 & 2,075 & $226(9.7)$ & $17(0.74)$ & $247(10.6)$ & 0.19 & 1.87 & 1.82 \\
\hline
\end{tabular}

${ }^{1} \mathrm{CS}=$ colostrum supplement $(70 \mathrm{~g}$ of dried colostrum powder $)$ added to milk replacer; PS = placebo supplement (70 g of nutritionally matched supplement without $\operatorname{IgG}$ ) added to milk replacer; UC = unsupplemented control.

${ }^{2}$ Feed consumption data reported for calves remaining in the study for $28 \mathrm{~d}$.

${ }^{3}$ Resp $=$ respiratory disease signs including pulmonary distress noted as thoracic or abdominal hyperventilation, and auscultation indicated congested lungs. 
$90 \%$ CI $=0.38-0.87)$ compared with unsupplemented control calves (Table 5). The risk for being treated with antimicrobials was increased for low-weight calves (compared with high-weight calves) and calves with FPT and PFPT (compared with APT calves).

Respiratory disease including heavy respiration or abdominal breathing was present in $1 \%$ of the observation calf-days (Table 3). There was no significant difference among treatment groups for respiratory scores $(P=0.25)$.

\section{ADG and Grain Intake}

Calves in the colostrum treatment group had a significantly greater ADG to $28 \mathrm{~d}$ of age than the calves in the unsupplemented control group (Table 6). Calves with FPT had a significantly lower ADG compared with APT calves. Low-weight calves had greater ADG during the first $28 \mathrm{~d}$ of life than heavier calves. Calves on ranches $\mathrm{A}$ and $\mathrm{B}$ gained more weight than calves on ranch C. At weaning $(60 \mathrm{~d})$, the only factors significantly affecting weight gain were IgG status and calf ranch (Table 7 ). The average daily grain intake for the first $28 \mathrm{~d}$ of life was greater in calves receiving the $14-\mathrm{d}$ colostrum or placebo supplement compared with the unsupplemented calves, in heavier weight calves, and in calves with PFPT or APT compared with FPT (Table $8)$. There were significant differences in grain consumption between animals on the 3 ranches.

\section{DISCUSSION}

This study indicates that post-gut-closure feeding of a colostrum supplement to calves was effective in reducing both days with diarrhea and associated antimicrobial treatments. Although the colostrum supplement was effective, adequate passive transfer of immunity was the most important predictor of calf health.

\section{Passive Transfer of Immunity}

The majority of calves arriving onto these calf ranches had FPT or PFPT, which was the most important predictor of mortality, morbidity, low weight gain, and low grain intake. In addition, there were no interactions between colostrum treatment and FPT for any of the health outcomes. Furthermore, the serum IgG measured on $\mathrm{d} 7$ on ranch A supports previous studies that post-gut-closure feeding of a colostrum supplement will not improve the passive systemic immunity (Stott et al., 1979). Therefore, the critical time to address failure of passive transfer in calf ranch calves is within the first $24 \mathrm{~h}$ after birth, and this needs to be addressed at the dairy of origin.

\section{Mortality}

There was no detectable difference in mortality between the treatment groups, and, consistent with previ-

Table 4. Results from a multivariate negative binomial model of total diarrhea days observed in calves during the first $28 \mathrm{~d}$ of life from 3 field trials (ranches A, B, and C) evaluating the efficacy of feeding a colostrum supplement in milk replacer for $14 \mathrm{~d}$ to preweaned calves

\begin{tabular}{|c|c|c|c|c|c|}
\hline \multirow[b]{2}{*}{ Variable } & \multirow[b]{2}{*}{ Level } & \multirow[b]{2}{*}{ Risk ratio } & \multicolumn{2}{|c|}{$90 \% \mathrm{CI}^{1}$} & \multirow[b]{2}{*}{$P$-value } \\
\hline & & & Lower & Upper & \\
\hline Treatment group ${ }^{2}$ & $\begin{array}{l}\text { CS } \\
\text { PS } \\
\text { UC }\end{array}$ & $\begin{array}{c}0.61 \\
1.07 \\
\text { Reference }\end{array}$ & $\begin{array}{l}0.49 \\
0.86 \\
-\end{array}$ & $\begin{array}{l}0.78 \\
1.32 \\
-\end{array}$ & $\begin{array}{c}<0.01 \\
0.61 \\
-\end{array}$ \\
\hline Weight category $^{3}$ & $\begin{array}{l}\text { Low } \\
\text { Mid } \\
\text { High }\end{array}$ & $\begin{array}{c}1.54 \\
1.34 \\
\text { Reference }\end{array}$ & $\begin{array}{l}1.18 \\
1.06 \\
-\end{array}$ & $\begin{array}{l}2.00 \\
1.69 \\
-\end{array}$ & $\begin{array}{c}<0.01 \\
0.04 \\
-\end{array}$ \\
\hline Serum IgG category ${ }^{4}$ & $\begin{array}{l}\text { FPT } \\
\text { PFPT } \\
\text { APT }\end{array}$ & $\begin{array}{c}2.88 \\
1.85 \\
\text { Reference }\end{array}$ & $\begin{array}{l}2.22 \\
1.50 \\
-\end{array}$ & $\begin{array}{l}3.71 \\
2.28 \\
-\end{array}$ & $\begin{array}{l}<0.01 \\
<0.01 \\
-\end{array}$ \\
\hline Calf ranch & $\begin{array}{l}\mathrm{A} \\
\mathrm{B} \\
\mathrm{C}\end{array}$ & $\begin{array}{c}1.70 \\
1.55 \\
\text { Reference }\end{array}$ & $\begin{array}{l}1.35 \\
1.20 \\
-\end{array}$ & $\begin{array}{l}2.14 \\
1.99 \\
-\end{array}$ & $\begin{array}{l}<0.01 \\
<0.01 \\
-\end{array}$ \\
\hline
\end{tabular}

${ }^{1} \mathrm{CI}=$ confidence interval.

${ }^{2} \mathrm{CS}=$ colostrum supplement (70 g of dried colostrum powder) added to milk replacer; PS = placebo supplement (70 g of nutritionally matched supplement without $\mathrm{IgG}$ ) added to milk replacer; $\mathrm{UC}=$ unsupplemented control.

${ }^{3}$ Low: $\leq 38.5 \mathrm{~kg}$; mid: between 38.6 and $45 \mathrm{~kg}$; high: $\geq 45 \mathrm{~kg}$.

${ }^{4} \mathrm{FPT}=$ failure of passive transfer: $\mathrm{IgG} \leq 350 \mathrm{mg} / \mathrm{dL} ; \mathrm{PFPT}=$ partial failure of passive transfer: IgG between (and including) 351 and $999 \mathrm{mg} / \mathrm{dL}$; and $\mathrm{APT}=$ adequate passive transfer: $\mathrm{IgG} \geq 1,000 \mathrm{mg} / \mathrm{dL}$. 
Table 5. Results from a multivariate proportional hazards model of the days to first antimicrobial treatment from 3 field trials (ranches A, B, and C) evaluating the efficacy of feeding a colostrum supplement in milk replacer for $14 \mathrm{~d}$ to preweaned calves

\begin{tabular}{|c|c|c|c|c|c|}
\hline \multirow[b]{2}{*}{ Variable } & \multirow[b]{2}{*}{ Level } & \multirow[b]{2}{*}{ Hazard ratio } & \multicolumn{2}{|c|}{$90 \% \mathrm{CI}^{1}$} & \multirow[b]{2}{*}{ Wald's $P$-value } \\
\hline & & & Lower & Upper & \\
\hline \multirow[t]{3}{*}{ Treatment group ${ }^{2}$} & $\mathrm{CS}$ & 0.57 & 0.38 & 0.87 & 0.03 \\
\hline & PS & 1.10 & 0.77 & 1.58 & 0.67 \\
\hline & UC & Reference & - & - & - \\
\hline \multirow[t]{3}{*}{ Weight category $^{3}$} & Low & 2.17 & 1.35 & 3.48 & 0.01 \\
\hline & Mid & 1.60 & 1.03 & 2.48 & 0.08 \\
\hline & High & Reference & - & - & - \\
\hline \multirow[t]{3}{*}{ Serum IgG status ${ }^{4}$} & $\mathrm{FPT}$ & 3.73 & 2.37 & 5.87 & $<0.01$ \\
\hline & PFPT & 1.89 & 1.26 & 2.82 & 0.01 \\
\hline & $\mathrm{APT}$ & Reference & - & - & - \\
\hline \multirow[t]{3}{*}{ Calf ranch } & $\mathrm{A}$ & 0.97 & 0.66 & 1.43 & 0.9 \\
\hline & B & 1.24 & 0.81 & 1.91 & 0.4 \\
\hline & $\mathrm{C}$ & Reference & - & - & - \\
\hline
\end{tabular}

${ }^{1} \mathrm{CI}=$ confidence interval.

${ }^{2} \mathrm{CS}=$ colostrum supplement $(70 \mathrm{~g}$ of dried colostrum powder $)$ added to milk replacer; PS = placebo supplement (70 g of nutritionally matched supplement without $\mathrm{IgG}$ ) added to milk replacer; UC = unsupplemented control.

${ }^{3}$ Low: $\leq 38.5 \mathrm{~kg}$; mid: between 38.6 and $45 \mathrm{~kg}$; high: $\geq 45 \mathrm{~kg}$.

${ }^{4} \mathrm{FPT}=$ failure of passive transfer: $\operatorname{IgG} \leq 350 \mathrm{mg} / \mathrm{dL} ;$ PFPT $=$ partial failure of passive transfer: $\operatorname{IgG}$ between (and including) 351 and $999 \mathrm{mg} / \mathrm{dL}$; and $\mathrm{APT}=$ adequate passive transfer: $\operatorname{IgG} \geq 1,000 \mathrm{mg} / \mathrm{dL}$.

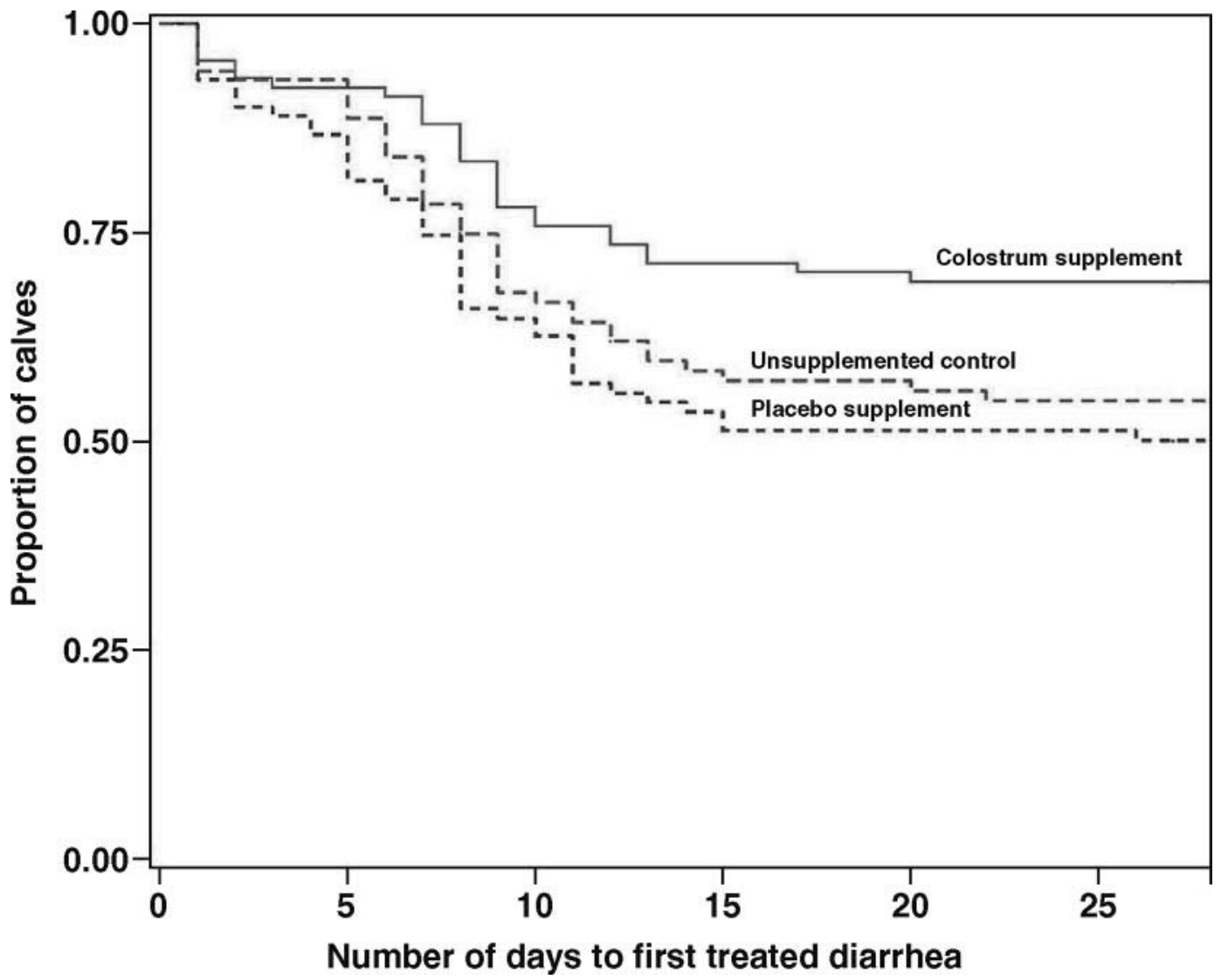

Figure 1. Kaplan-Meier plot showing days to first treated diarrhea stratified by treatment group in 3 field trials evaluating the efficacy of feeding a colostrum supplement in milk replacer for $14 \mathrm{~d}$ to preweaned calves (Wilcoxon test of equality of strata, $\chi^{2}=7.53 ; P=0.02$ ). 
Table 6. Results from a multivariate GLM $^{1}$ modeling 28-d ADG in 3 field trials (ranches A, B, and C) evaluating the efficacy of feeding a colostrum supplement in milk replacer for $14 \mathrm{~d}$ to preweaned calves $(\mathrm{n}=$ 235)

\begin{tabular}{|c|c|c|c|c|c|}
\hline \multirow[b]{2}{*}{ Variable } & \multirow[b]{2}{*}{ Level } & \multirow[b]{2}{*}{$\begin{array}{c}\text { LSM } \\
\text { Estimate, }{ }^{2} \mathrm{~kg}\end{array}$} & \multirow[b]{2}{*}{$P$-value } & \multicolumn{2}{|c|}{$90 \% \mathrm{CI}^{3}$} \\
\hline & & & & Lower & Upper \\
\hline \multirow[t]{3}{*}{ Treatment group ${ }^{4}$} & $\mathrm{CS}$ & 0.24 & 0.04 & 0.22 & 0.27 \\
\hline & PS & 0.22 & 0.39 & 0.19 & 0.25 \\
\hline & UC & 0.20 & Reference & 0.17 & 0.23 \\
\hline \multirow[t]{3}{*}{ Serum IgG category ${ }^{5}$} & $\mathrm{FPT}$ & 0.15 & $<0.01$ & 0.11 & 0.20 \\
\hline & PFPT & 0.24 & 0.12 & 0.21 & 0.26 \\
\hline & $\mathrm{APT}$ & 0.27 & Reference & 0.25 & 0.29 \\
\hline \multirow[t]{3}{*}{ Weight category ${ }^{6}$} & Low & 0.27 & $<0.01$ & 0.24 & 0.30 \\
\hline & Mid & 0.23 & $<0.01$ & 0.20 & 0.25 \\
\hline & High & 0.16 & Reference & 0.13 & 0.20 \\
\hline \multirow[t]{3}{*}{ Calf ranch } & $\mathrm{A}$ & 0.33 & $<0.01$ & 0.31 & 0.36 \\
\hline & $\mathrm{B}$ & 0.12 & $<0.01$ & 0.10 & 0.16 \\
\hline & $\mathrm{C}$ & 0.21 & Reference & 0.18 & 0.24 \\
\hline
\end{tabular}

${ }^{1} F$-value $=16.16 ; \mathrm{df}=8 ; P<0.0001 ;$ and $\mathrm{R}^{2}=0.36$.

${ }^{2}$ Least squares mean estimate.

${ }^{3} \mathrm{CI}=$ confidence interval.

${ }^{4} \mathrm{CS}=$ colostrum supplement $(70 \mathrm{~g}$ of dried colostrum powder) added to milk replacer; PS = placebo supplement (70 g of nutritionally matched supplement without $\mathrm{IgG}$ ) added to milk replacer; UC = unsupplemented control.

${ }^{5} \mathrm{FPT}=$ failure of passive transfer: $\operatorname{IgG} \leq 350 \mathrm{mg} / \mathrm{dL} ; \mathrm{PFPT}=$ partial failure of passive transfer: $\operatorname{IgG}$ between (and including) 351 and $999 \mathrm{mg} / \mathrm{dL}$; and APT = adequate passive transfer: $\mathrm{IgG} \geq 1,000 \mathrm{mg} / \mathrm{dL}$.

${ }^{6} \mathrm{Low}: \leq 38.5 \mathrm{~kg}$; mid: between 38.6 and $45 \mathrm{~kg}$; high: $\geq 45 \mathrm{~kg}$.

Table 7. Results from a multivariate $\mathrm{GLM}^{1}$ modeling $60-\mathrm{d}$ ADG in 3 field trials (ranches A, B, and C) evaluating the efficacy of feeding a colostrum supplement in milk replacer for $14 \mathrm{~d}$ to preweaned calves $(\mathrm{n}=$ $176)^{2}$

\begin{tabular}{|c|c|c|c|c|c|}
\hline \multirow[b]{2}{*}{ Variable } & \multirow[b]{2}{*}{ Level } & \multirow{2}{*}{$\begin{array}{c}\mathrm{LSM} \\
\text { estimate, }{ }^{3} \mathrm{~kg}\end{array}$} & \multirow[b]{2}{*}{$P$-value } & \multicolumn{2}{|c|}{$90 \% \mathrm{CI}^{4}$} \\
\hline & & & & Lower & Upper \\
\hline \multirow[t]{3}{*}{ Treatment group 5} & $\mathrm{CS}$ & 0.48 & 0.44 & 0.44 & 0.51 \\
\hline & PS & 0.44 & 0.63 & 0.41 & 0.48 \\
\hline & $\mathrm{UC}$ & 0.45 & Reference & 0.42 & 0.49 \\
\hline \multirow[t]{3}{*}{ Serum IgG category ${ }^{6}$} & $\mathrm{FPT}$ & 0.39 & $<0.01$ & 0.33 & 0.44 \\
\hline & PFPT & 0.48 & 0.24 & 0.45 & 0.51 \\
\hline & $\mathrm{APT}$ & 0.51 & Reference & 0.48 & 0.54 \\
\hline \multirow[t]{3}{*}{ Weight category $^{7}$} & Low & 0.46 & 0.62 & 0.42 & 0.50 \\
\hline & Mid & 0.47 & 0.38 & 0.44 & 0.50 \\
\hline & High & 0.44 & Reference & 0.41 & 0.48 \\
\hline \multirow[t]{3}{*}{ Calf ranch } & $\mathrm{A}$ & 0.63 & $<0.01$ & 0.60 & 0.66 \\
\hline & B & 0.43 & $<0.01$ & 0.40 & 0.46 \\
\hline & $\mathrm{C}$ & 0.31 & Reference & 0.26 & 0.37 \\
\hline
\end{tabular}

${ }^{1} F$-value $=16.49 ; \mathrm{df}=8 ; P<0.0001 ;$ and $\mathrm{R}^{2}=0.44$.

${ }^{2}$ Calves were lost to follow-up in the routine movement of calves within the calf ranches and because of a management change on ranch $\mathrm{C}$ that resulted in calves returning to the source farm at 1 mo of age.

${ }^{3}$ Least squares mean estimate.

${ }^{4} \mathrm{CI}=$ confidence interval.

${ }^{5} \mathrm{CS}=$ colostrum supplement (70 g of dried colostrum powder) added to milk replacer; PS = placebo supplement (70 g of nutritionally matched supplement without $\mathrm{IgG}$ ) added to milk replacer; UC = unsupplemented control.

${ }^{6} \mathrm{FPT}$ = failure of passive transfer: $\operatorname{IgG} \leq 350 \mathrm{mg} / \mathrm{dL}$; PFPT $=$ partial failure of passive transfer: IgG between (and including) 351 and $999 \mathrm{mg} / \mathrm{dL}$; and $\mathrm{APT}=$ adequate passive transfer: $\mathrm{IgG} \geq 1,000 \mathrm{mg} / \mathrm{dL}$.

${ }^{7}$ Low: $\leq 38.5 \mathrm{~kg}$; mid: between 38.6 and $45 \mathrm{~kg}$; high: $\geq 45 \mathrm{~kg}$. 
Table 8. Results from a multivariate GLM $^{1}$ modeling 28-d average daily grain consumption in 3 field trials (ranches A, B, and C) evaluating the efficacy of feeding a colostrum supplement in milk replacer for $14 \mathrm{~d}$ to preweaned calves $(\mathrm{n}=235)$

\begin{tabular}{|c|c|c|c|c|c|}
\hline \multirow[b]{2}{*}{ Variable } & \multirow[b]{2}{*}{ Level } & \multirow{2}{*}{$\begin{array}{c}\text { LSM } \\
\text { estimate, }{ }^{2} \mathrm{~kg}\end{array}$} & \multirow[b]{2}{*}{$P$-value } & \multicolumn{2}{|c|}{$90 \% \mathrm{CI}^{3}$} \\
\hline & & & & Lower & Upper \\
\hline \multirow[t]{3}{*}{ Treatment group ${ }^{4}$} & $\mathrm{CS}$ & 0.22 & $<0.01$ & 0.19 & 0.24 \\
\hline & PS & 0.21 & 0.02 & 0.19 & 0.23 \\
\hline & $\mathrm{UC}$ & 0.17 & Reference & 0.15 & 0.19 \\
\hline \multirow[t]{3}{*}{ Serum IgG category $^{5}$} & $\mathrm{FPT}$ & 0.16 & $<0.01$ & 0.12 & 0.19 \\
\hline & PFPT & 0.22 & 0.58 & 0.20 & 0.23 \\
\hline & $\mathrm{APT}$ & 0.23 & Reference & 0.21 & 0.24 \\
\hline \multirow[t]{3}{*}{ Weight category $^{6}$} & Low & 0.17 & $<0.01$ & 0.15 & 0.19 \\
\hline & Mid & 0.20 & 0.20 & 0.19 & 0.22 \\
\hline & High & 0.22 & Reference & 0.20 & 0.25 \\
\hline \multirow[t]{3}{*}{ Calf ranch } & $\mathrm{A}$ & 0.28 & $<0.01$ & 0.26 & 0.30 \\
\hline & B & 0.21 & $<0.01$ & 0.19 & 0.23 \\
\hline & $\mathrm{C}$ & 0.10 & Reference & 0.08 & 0.13 \\
\hline
\end{tabular}

${ }^{1} F$-value $=20.17 ; \mathrm{df}=8 ; P<0.0001 ;$ and $\mathrm{R}^{2}=0.42$.

${ }^{2}$ Least squares mean estimate.

${ }^{3} \mathrm{CI}=$ confidence interval.

${ }^{4} \mathrm{CS}=$ colostrum supplement $(70 \mathrm{~g}$ of dried colostrum powder $)$ added to milk replacer; $\mathrm{PS}=$ placebo supplement (70 g of nutritionally matched supplement without $\mathrm{IgG}$ ) added to milk replacer; $\mathrm{UC}=$ unsupplemented control.

${ }^{5} \mathrm{FPT}=$ failure of passive transfer: $\mathrm{IgG} \leq 350 \mathrm{mg} / \mathrm{dL} ; \mathrm{PFPT}=$ partial failure of passive transfer: IgG between (and including) 351 and $999 \mathrm{mg} / \mathrm{dL}$; and APT = adequate passive transfer: $\operatorname{IgG} \geq 1,000 \mathrm{mg} / \mathrm{dL}$.

${ }^{6} \mathrm{Low}: \leq 38.5 \mathrm{~kg}$; mid: between 38.6 and $45 \mathrm{~kg}$; high: $\geq 45 \mathrm{~kg}$.

ous studies, the most important factor associated with mortality was FPT (Donovan et al., 1998; Berge et al., 2005). Despite our efforts to develop management approaches to ameliorate the negative impacts of FPT on calf mortality, we have yet to find an effective strategy. The high mortality on ranch $\mathrm{C}$ was attributed to a salmonellosis outbreak in the calves during a period of severe heat stress. Several study calves on ranch C had bloody diarrhea, and the calf pathogenic Salmonella enterica serovar Newport was recovered from fecal samples from ten 2-wk-old calves and four 4-wk-old calves, as well as from 4 postmortem samples of septicemic calves (A. C. B. Berge, personal communication). The failure to successfully treat these calves for diarrheal and systemic disease is likely due to an interaction between FPT and the virulence of the Salmonella Newport serovar, which has been reported as a calf and cow pathogen resulting in high mortality and resistant to the antimicrobials in the treatment protocols (Berge et al., 2004).

\section{Morbidity}

Colostrum supplement added to calf milk replacer for the first $14 \mathrm{~d}$ of life significantly reduced the number of days the calves had diarrhea and decreased the use of therapeutic antimicrobials in calves. This effect was likely due to the presence of colostral immunoglobulins and not simply a nutritional benefit of colostrum, as this same effect on diarrhea and treatment was not observed in the placebo-supplemented calves. Several clinical studies have demonstrated that colostrum or blood plasma immunoglobulins can provide local immunity against several pathogens associated with calf diarrheal disease such as Escherichia coli, rota virus, and corona virus (Acres, 1985; Arthington et al., 1985; Crouch et al., 2000).

The IgG supplement used for our study was pasteurized and spray-dried first-day colostrum. A study feeding milk replacer containing $5 \%$ bovine or porcine plasma to calves containing $16.8 \%$ (DM) immunoglobulins resulted in decreased morbidity and mortality due to enteric disease (Quigley and Wolfe, 2003). Other non-IgG factors in the colostrum supplement (e.g., epidermal growth factor and tumor necrosis factor- $\alpha$ ) that protect the gut through mucosal growth and healing (Jaeger et al., 1987; Burrin et al., 1995; Blum and Hammon, 2000) may also have contributed to the decrease in diarrhea. A comparison of feeding serum-derived blood plasma containing immunoglobulins and colostrum or colostrum supplement could further elucidate the components in the colostrum that are critical to optimize calf gut health.

Low-weight calves had more diarrhea days than heavier calves. All study calves were Holstein dairy 
source calves and there was no significant difference in passive transfer status to explain the increased diarrhea in low-weight calves. The increased diarrhea may be a result of low-weight calves being fed more milk in relation to BW (all calves received the same volume of milk replacer), resulting in greater fecal output than the heavier calves (Heath et al., 1989). The increased rate of diarrhea on ranches $\mathrm{A}$ and $\mathrm{B}$ compared with $\mathrm{C}$ is likely explained by the greater numbers of calves on ranch $\mathrm{C}$ that died acutely, before observed signs of disease.

\section{ADG and Grain Consumption}

The colostrum-supplemented calves gained more weight by $28 \mathrm{~d}$ of age compared with control calves, but by $60 \mathrm{~d}$ of age there was no difference in ADG between the groups. The early weight gain difference for the CS calves may be due to additional nutrients from the colostrum supplement (Godden, 2008) and the observed increased grain consumption in this group. The placebo supplemented group also had greater grain consumption compared with controls, but the ADG at $28 \mathrm{~d}$ was not significantly different from controls. The increased grain intake in calves receiving a greater level of nutrition through the milk is in contrast to studies indicating that increased energy intake through the milk replacer leads to decreased grain intake in preweaned calves (Kuehn et al., 1994; Drackley, 2008). The greater weight gain in the colostrum-supplemented calves compared with the placebo-supplemented and control calves may be because of lower rates of morbidity. Diseases causing inflammation resulting in the release of cytokines can activate homeorhetic responses to direct nutrients from tissue deposition (i.e, weight gain) toward immunologic defense functions (Colditz, 2004). The ADG was greater in low-weight calves, most likely because these calves received more milk per kilogram of BW than heavier calves as all calves received similar quantities of milk replacer regardless of arrival weight. The calves with FPT also had lesser weight gains likely because of decreased nutrient utilization and reduced feed intake associated with more disease in these calves compared with calves with APT (Colditz, 2004). The only significant factors affecting weaning weight were FPT and the calf ranch. Different levels of grain intake on these ranches may partly explain the weaning weight differences. The relatively smaller weight gains in calves on calf ranch $\mathrm{C}$ compared with ranches $\mathrm{A}$ and $\mathrm{B}$ may also have been due to heat stress (Drackley, 2008).

\section{CONCLUSIONS}

Although ensuring that calves have APT is the most significant management factor to ensure the health of neonatal calves on calf ranches, colostrum supplementation during the first $2 \mathrm{wk}$ of life in calves was effective in reducing diarrheal disease and the use of antimicrobials. The ADG up to $4 \mathrm{wk}$ of age in colostrumsupplemented calves was significantly greater compared with that in control calves, likely because of a combination of greater energy intake through the liquid feed, increased grain intake, and fewer days with diarrhea. Calf ranch systems need to continue to address problems of colostrum-deprived calves, pathogen load, and environmental stress to successfully raise calves and minimize prophylactic and therapeutic antibiotic use. Supplementing calves with a colostrum product may be a valuable tool to achieve these goals.

\section{ACKNOWLEDGMENTS}

The author would like to thank the 3 calf ranches for excellent collaboration. For technical assistance, we are in gratitude to Katrin Newman, Marla Hartman, Jennifer Crook, Kristina Maloy, Arlynn Hurtado and Ana Tejeda (University of California, Davis). The colostrum supplement was provided by Saskatoon Colostrum Company. Calva Products Inc. developed and produced the placebo supplement and provided advice on calf nutrition. This project was supported by USDA-CSREES-NIFSI Integrated Approaches for Food Safety (Project number 2004-00728), California Dairy Research Foundation, and Center for Food Animal Health-SVM University of California.

\section{REFERENCES}

Acres, S. D. 1985. Enterotoxigenic Escherichia coli infections in newborn calves: A review. J. Dairy Sci. 68:229-256.

Allison, P. D. 2005. Poisson regression. Pages 217-227 in Logistic Regression Using $\mathrm{SAS}^{\circledast}$ : Theory and Application. P. D. Allison, ed. SAS Institute Inc., Cary, NC.

Allison, P. D. 2007. Estimating Cox regression models with PROC PHREG. Pages 111-183 in Survival Analysis using SAS ${ }^{\circledast}$ : A Practical Guide. P. D. Allison, ed. SAS Institute Inc., Cary, NC.

Arthington, J. D., C. A. Jaynes, H. D. Tyler, S. Kapil, and J. D. Quigley III. 1985. The use of bovine serum protein as an oral support therapy following coronavirus challenge in calves. J. Dairy Sci. 85:1249-1254.

Berge, A. C., J. M. Adaska, and W. M. Sischo. 2004. Use of antibiotic susceptibility patterns and pulsed-field gel electrophoresis to compare historic and contemporary isolates of multi-drug-resistant Salmonella enterica subsp. enterica serovar Newport. Appl. Environ. Microbiol. 70:318-323.

Berge, A. C., P. Lindeque, D. A. Moore, and W. M. Sischo. 2005. A clinical trial evaluating prophylactic and therapeutic antibiotic 
use on health and performance of calves. J. Dairy Sci. 88:21662177.

Besser, T. E., and C. C. Gay. 1994. The importance of colostrum to the health of the neonatal calf. Vet. Clin. North Am. Food Anim. Pract. 10:107-117.

Besser, T. E., C. C. Gay, and L. Pritchett. 1991. Comparison of three methods of feeding colostrum to dairy calves. J. Am. Vet. Med. Assoc. 198:419-422.

Blum, J. W., and H. Hammon. 2000. Colostrum effects on the gastrointestinal tract, and on nutritional, endocrine and metabolic parameters in neonatal calves. Livest. Prod. Sci. 66:151-159.

Braidwood, J. C., and N. W. Henry. 1990. Clinical efficacy of chlortetracycline hydrochloride administered in milk replacer to calves. Vet. Rec. 127:297-301.

Buhler, C., H. Hammon, G. L. Rossi, and J. W. Blum. 1998. Small intestinal morphology in eight-day-old calves fed colostrum for different durations or only milk replacer and treated with longR3-insulin-like growth factor I and growth hormone. J. Anim. Sci. 76:758-765.

Burrin, D. G., T. A. Davis, S. Ebner, P. A. Schoknecht, M. L. Fiorotto, P. J. Reeds, and S. McAvoy. 1995. Nutrient-independent and nutrient-dependent factors stimulate protein synthesis in colostrum-fed newborn pigs. Pediatr. Res. 37:593-599.

Colditz, I. G. 2004. Some mechanisms regulating nutrient utilization in livestock during immune activation: An overview. Aust. J. Exp. Agric. 44:453-457.

Constable, P. D. 2003. Use of antibiotics to prevent calf diarrhea and septicemia. Bovine Pract. 37:137-142.

Crouch, C. F., S. Oliver, D. C. Hearle, A. Buckley, A. J. Chapman, and M. J. Francis. 2000. Lactogenic immunity following vaccination of cattle with bovine coronavirus. Vaccine 19:189-196.

Donovan, G. A., I. R. Dohoo, D. M. Montgomery, and F. L. Bennett. 1998. Associations between passive immunity and morbidity and mortality in dairy heifers in Florida, USA. Prev. Vet. Med. 34:3146.

Drackley, J. K. 2008. Calf nutrition from birth to breeding. Vet. Clin. Food Anim. 24:55-86.

FAO/WHO/OIE. 2008. Joint FAO/WHO/OIE expert meeting on critically important antimicrobials. World Health Organization. http://www.who.int/foodborne_disease/resources/Report\%20 joint\%20CIA\%20Meeting.pdf Accessed June 1, 2008.

Glantz, P. J., D. C. Kradel, and S. A. Seward. 1974. Esherichia coli and Salmonella newport in calves: Efficacy of prophylactic and therapeutic treatment. Vet. Med. Small Anim. Clin. 69:77-82.

Godden, S. 2008. Colostrum management for dairy calves. Vet. Clin. Food Anim. 24:19-39.

Heath, S. E., J. M. Naylor, B. L. Guedo, L. Petrie, C. G. Rousseaux, and O. M. Radostits. 1989. The effects of feeding milk to diarrheic calves supplemented with oral electrolytes. Can. J. Vet. Res. 53:477-485.
Hollander, M., and D. A. Wolfe. 1999. A distribution-free test for ordered alternatives. Section 6.2. Pages 202-211 in Nonparametric Statistical Methods. 2nd ed. John Wiley and Sons, New York, NY.

Hopkins, B. A., and J. D. Quigley. 1997. Effects of method of colostrum feeding and colostrum supplementation on concentrations of immunoglobulin G in the serum of neonatal calves. J. Dairy Sci. 80:979-983.

Hosmer, D. W., and S. Lemeshow. 1999. Applied Survival Analysis: Regression modeling of time to event data. John Wiley and Sons Inc. New York, NY.

Jaeger, L. A., C. H. Lamar, G. D. Bottoms, and T. R. Cline. 1987. Growth-stimulating substances in porcine milk. Am. J. Vet. Res. 48:1531-1533.

Kuehn, C. S., D. E. Otterby, J. G. Linn, W. G. Olson, H. ChesterJones, G. D. Marx, and J. D. Barmore. 1994. The effect of dietary energy concentration on calf performance. J. Dairy Sci. 77:26212629.

Quigley, J. D., J. J. Drewry, L. M. Murray, and S. J. Ivey. 1997. Body weight gain, feed efficiency, and fecal scores of dairy calves in response to galactosyl-lactose or antibiotics in milk replacers. J. Dairy Sci. 80:1751-1754.

Quigley, J. D. III, and T. M. Wolfe. 2003. Effects of spray-dried animal plasma in calf milk replacer on health and growth of dairy calves. J. Dairy Sci. 86:586-592.

Saif, L. J., and E. H. Bohl. 1983. Passive immunity to transmissible gastroenteritis virus: Intramammary viral inoculation of sows. Ann. N. Y. Acad. Sci. 409:708-723.

Silbergeld, E. K., J. Graham, and L. B. Price. 2008. Industrial food animal production, antimicrobial resistance, and human health. Annu. Rev. Public Health 29:151-169.

Snodgrass, D. R., K. J. Fahey, P. W. Wells, I. Campbell, and A Whitelaw. 1980. Passive immunity in calf rotavirus infections: Maternal vaccination increases and prolongs immunoglobulin G1 antibody secretion in milk. Infect. Immun. 28:344-349.

Snodgrass, D. R., J. Stewart, J. Taylor, F. L. Krautil, and M. L. Smith. 1982. Diarrhoea in dairy calves reduced by feeding colostrum from cows vaccinated with rotavirus. Res. Vet. Sci. 32:70-73.

Stott, G. H., D. B. Marx, B. E. Menefee, and G. T. Nightengale. 1979. Colostral immunoglobulin transfer in calves I. Period of absorption. J. Dairy Sci. 62:1632-1638.

Tyler, J. W., D. D. Hancock, S. M. Parish, D. E. Rea, T. E. Besser, S. G. Sanders, and L. K. Wilson. 1996. Evaluation of 3 assays for failure of passive transfer in calves. J. Vet. Intern. Med. 10:304307.

Weaver, D. M., J. W. Tyler, D. C. VanMetre, D. E. Hostetler, and G. M. Barrington. 2000. Passive transfer of colostral immunoglobulins in calves. J. Vet. Intern. Med. 14:569-577. 